九州大学学術情報リポジトリ

Kyushu University Institutional Repository

\title{
Characterization of Erwinia carotovora subsp. carotovora Strains on the Basis of Cellular Fatty Acid Composition
}

Seo, Sang-Tae

Laboratory of Plant Pathology, Division of Plant Pathology and Pesticide Science, Graduate School of Bioresource and Bioenvironmental Sciences, Kushu University

Furuya, Naruto

Laboratory of Plant Pathology, Division of Plant Pathology and Pesticide Science, Department of Appliied Genetics and Pest Management, Faculty of Agriculture, Kyushu University

Takanami, Yoichi

Laboratory of Plant Pathology, Division of Plant Pathology and Pesticide Science, Department of Appliied Genetics and Pest Management, Faculty of Agriculture, Kyushu University

https://doi.org/10.5109/24437

出版情報 : 九州大学大学院農学研究院紀要. 46 (2)，pp. 251-256，2002-02-28. Kyushu University バージョン：

権利関係 : 


\title{
Characterization of Erwinia carotovora subsp. carotovora Strains on the Basis of Cellular Fatty Acid Composition
}

\author{
Sang-Tae SEO*, Naruto FURUYA and Yoichi TAKANAMI \\ Laboratory of Plant Pathology, Division of Plant Pathology and Pesticide Science, Department of Applied \\ Genetics and Pest Management, Faculty of Agriculture, Kyushu University, Fukuoka 812-8581, Japan \\ (Received September 17, 2001 and accepted November 20, 2001)
}

\begin{abstract}
Eighty-seven strains of Erwinia carotovora subsp. carotovora (Ecc) isolated from various host plants in several geographic regions of Asia during different years, were characterized by their fatty acid compositions. All strains contained, in decreasing order of amount present, lauric acid (12:0), palmitic acid (16:0), palmitoleic acid (16:1 cis 9), vaccenic acid (18:1 cis 11) and one unidentified fatty acid (Un-3). Also present in some but not all strains were capric acid (10:0), myristic acid (14:0), 3-hydroxylauric acid (12:0 3-OH), stearic acid (18:0), linoleic acid (18:3 cis 9,12) and four unidentified fatty acids (Un-1, Un-2, Un-4 and Un-5). In cluster analysis based on the fatty acid composition, the Ecc strains were composed of two groups (I and $\mathbb{I})$. When the strains were grouped according to their geographical origins, some relationships were found. All Korean and most of Thai strains belonged to the group II, while Japanese isolates belonged to the both groups.
\end{abstract}

\section{INTRODUCTION}

The plant pathogenic enterobacterium Erwinia carotovora subsp. carotovora (Ecc) belongs to the soft rot group of erwinias and has the ability to infect a number of plant species, including several economically important crops. Previous attempts to characterize Ecc strains on the basis of pathogenicity and biochemical characteristics (Lelliot and Dickey, 1984; Smith and Bartz, 1990), serology (De Boer et al., 1987) and molecular biology (Darrasse et al., 1994) have shown that there is a great deal of variability in this subspecies.

Fatty acid analysis has become a valuable taxonomic tool in classification of plant pathogenic bacteria (Moss, 1981). Some groups of bacteria have profiles sufficiently different from each other to permit differentiation based on a few calculated parameters, such as percentages of individual fatty acids. The fatty acid analyses of $E$. carotovora have been described (De Boer and Sasser, 1986; Wells and Moline, 1991). However, little is known about detailed characterization of Ecc strains in Asian areas. In this study, we examine the cellular fatty acid compositions of Ecc strains isolated from Thailand, Korea and Japan by gas-liquid chromatography.

\section{MATERIALS AND METHODS}

\section{Bacterial strains}

Relevant characteristics of Ecc strains used in this study are listed in Table 1. All the

\footnotetext{
* Laboratory of Plant Pathology, Division of Plant Pathology and Pesticide Science, Graduate School of
} Bioresource and Bioenvironmental Sciences, Kyushu University, Fukuoka 812-8581, Japan 
Table 1. Origins and groupings of $E$. carotovora subsp. carotovora strains by fatty acid composition

\begin{tabular}{|c|c|c|c|c|c|}
\hline Strain & Source & Isolated from & $\begin{array}{c}\text { Year } \\
\text { isolated }\end{array}$ & Group ${ }^{a}$ & Cluster $^{3)}$ \\
\hline $014-2$ & Thailand & Cauliflower & 1980 & I & $\mathrm{B}$ \\
\hline $014-9$ & Thailand & Cauliflower & 1980 & II & $\mathrm{E}$ \\
\hline $131-1$ & Thailand & Bell pepper & 1980 & II & $\mathrm{G}$ \\
\hline $168-7$ & Thailand & Chinese cabbage & 1980 & II & $\mathrm{G}$ \\
\hline $435-2$ & Thailand & Lettuce & 1982 & II & $\mathrm{G}$ \\
\hline $435-6$ & Thailand & Lettuce & 1982 & II & $\mathrm{E}$ \\
\hline $462-53-1$ & Thailand & Tomato & 1982 & II & $G$ \\
\hline $473-1$ & Thailand & Chinese cabbage & 1982 & II & $\mathrm{G}$ \\
\hline $475-1$ & Thailand & Hot pepper & 1982 & II & $\mathrm{E}$ \\
\hline $476-4$ & Thailand & Bird chili & 1982 & II & $\mathrm{E}$ \\
\hline $476-7$ & Thailand & Bird chili & 1982 & II & $\mathrm{E}$ \\
\hline $479-2$ & Thailand & Coriander & 1982 & II & $\mathrm{E}$ \\
\hline $485-5$ & Thailand & Cabbage & 1982 & II & $\mathrm{G}$ \\
\hline $486-4$ & Thailand & Sweet pepper & 1982 & I & $\mathrm{A}$ \\
\hline $486-5$ & Thailand & Sweet pepper & 1982 & II & $\mathrm{E}$ \\
\hline $486-7$ & Thailand & Sweet pepper & 1982 & II & $E$ \\
\hline $486-8$ & Thailand & Sweet pepper & 1982 & II & $\mathrm{E}$ \\
\hline $489-4$ & Thailand & Cabbage & 1982 & II & $\mathrm{E}$ \\
\hline $489-5$ & Thailand & Cabbage & 1982 & II & $\mathrm{E}$ \\
\hline $493-1$ & Thailand & Potato & 1982 & II & $\mathrm{E}$ \\
\hline $493-3$ & Thailand & Potato & 1982 & II & $\mathrm{G}$ \\
\hline $493-5$ & Thailand & Potato & 1982 & I & $\mathrm{A}$ \\
\hline N7101 & Japan & Sweet pepper & 1971 & II & $\mathrm{E}$ \\
\hline N7109 & Japan & Cauliflower & 1971 & II & $\mathrm{E}$ \\
\hline N7116 & Japan & Cabbage & 1971 & II & $\mathrm{G}$ \\
\hline N7127 & Japan & Carrot & 1971 & I & $\mathrm{A}$ \\
\hline N7128 & Japan & Celery & 1971 & $I$ & $\mathrm{~A}$ \\
\hline N7129 & Japan & Radish & 1971 & I & $A$ \\
\hline N7131 & Japan & Tomato & 1971 & 1 & $\mathrm{~A}$ \\
\hline N7135 & Japan & Tomato & 1971 & II & $\mathrm{G}$ \\
\hline N7157 & Japan & Chinese cabbage & 1971 & I & $\mathrm{A}$ \\
\hline Ku7514 & Japan & Water melon & 1975 & $I$ & A \\
\hline Sr79-33-3 & Japan & Potato & 1979 & I & A \\
\hline S8488 & Japan & Sunflower & 1984 & I & $\mathrm{C}$ \\
\hline $1 \mathrm{~B}$ & Japan & Shallot & 1982 & II & $\mathrm{G}$ \\
\hline 190 & Japan & Carrot & 1984 & II & $\mathrm{E}$ \\
\hline 43 & Japan & Cabbage & 1984 & I & A \\
\hline $645 \mathrm{ar}$ & Japan & Chinese cabbage & 1960 & 1 & $A$ \\
\hline Arl3 & Japan & Chinese cabbage & 1960 & II & G \\
\hline 20 & Japan & Chinese cabbage & 1970 & I & $\mathrm{A}$ \\
\hline EH8504 & Japan & Cucumber & 1985 & I & $\mathrm{A}$ \\
\hline EH8510 & Japan & Cucumber & 1985 & 1 & $\mathrm{~A}$ \\
\hline EH8514 & Japan & Cucumber & 1985 & 1 & $\mathrm{~A}$ \\
\hline EH8519 & Japan & Cucumber & 1985 & II & $\mathrm{G}$ \\
\hline B1 & Japan & Broccoli & 1985 & II & G \\
\hline $\mathrm{K} 1$ & Japan & Radish & 1985 & II & $\mathrm{E}$ \\
\hline
\end{tabular}


Table 1. Continued

\begin{tabular}{|c|c|c|c|c|c|}
\hline Strain & Source & Isolated from & $\begin{array}{c}\text { Year } \\
\text { isolated }\end{array}$ & Group & Cluster \\
\hline $\mathrm{K} 2$ & Japan & Radish & 1985 & II & $G$ \\
\hline MAFF' 106567 & Japan & Cucumber & 1985 & II & $\mathrm{E}$ \\
\hline MAFF 301049 & Japan & Eggplant & 1948 & I & $\mathrm{D}$ \\
\hline MAFF 301053 & Japan & Radish & 1957 & I & $\mathrm{D}$ \\
\hline MAFF 301282 & Japan & Melon & 1976 & II & $\mathrm{G}$ \\
\hline MAFF 301394 & Japan & Cabbage & 1971 & I & $\mathrm{D}$ \\
\hline MAFF 301396 & Japan & Carrot & 1971 & II & $\mathrm{E}$ \\
\hline MAFF 301399 & Japan & Elephant's foot & 1971 & II & $\mathrm{E}$ \\
\hline MAFF 301404 & Japan & Parsley & 1973 & I & $\mathrm{D}$ \\
\hline MAFF 301891 & Japan & Sweet pepper & 1971 & II & $\mathrm{E}$ \\
\hline MAFF 301905 & Japan & Tobacco & 1971 & II & $\mathrm{E}$ \\
\hline MAFF 301917 & Japan & Cauliflower & 1971 & I & $\mathrm{D}$ \\
\hline MAFF 301937 & Japan & Mulberry & 1974 & II & $\mathrm{E}$ \\
\hline MAFF 301941 & Japan & Ginger & 1974 & II & $\mathrm{E}$ \\
\hline MAFF 302107 & Japan & Japanese angelica tree & 1988 & I & $\mathrm{D}$ \\
\hline MAFF 302773 & Japan & Garlic & 1983 & 1 & $\mathrm{D}$ \\
\hline MAFF 311115 & Japan & Calla & 1994 & 1 & $\mathrm{D}$ \\
\hline MAFF 810035 & Japan & Lettuce & 1980 & II & $\mathrm{E}$ \\
\hline Eccl/95 & Korea & Wasabi & 1995 & II & $\mathrm{E}$ \\
\hline Ecc2/95 & Korea & Chicory & 1995 & II & $F$ \\
\hline Ecc3/95 & Korea & Potato & 1995 & II & $F$ \\
\hline Ecc $4 / 95$ & Korea & Chinese cabbage & 1995 & II & G \\
\hline Ecc5/95 & Korea & Chinese cabbage & 1995 & II & $\mathrm{F}$ \\
\hline Ecc6/95 & Korea & Potato & 1995 & II & $\mathrm{G}$ \\
\hline Ecc1/96 & Korea & Chinese cabbage & 1996 & II & $\mathrm{G}$ \\
\hline Ecc2/96 & Korea & Chinese cabbage & 1996 & II & $\mathrm{G}$ \\
\hline Ecc3/96 & Korea & Chinese cabbage & 1996 & II & $\mathrm{G}$ \\
\hline Ecc $4 / 96$ & Korea & Chinese cabbage & 1996 & II & $G$ \\
\hline Ecc5/96 & Korea & Chinese cabbage & 1996 & II & $\mathrm{G}$ \\
\hline Ecc6/96 & Korea & Wasabi & 1996 & II & $\mathrm{G}$ \\
\hline Ecc7/96 & Korea & Onion & 1996 & II & $\mathrm{E}$ \\
\hline Ecc8/96 & Korea & Crisphead lettuce & 1996 & II & $\mathrm{E}$ \\
\hline Ecc9/96 & Korea & Radish & 1996 & II & $\mathrm{E}$ \\
\hline Eccl1/96 & Korea & Potato & 1996 & II & $G$ \\
\hline Ecc12/96 & Korea & Cucumber & 1996 & II & $\mathrm{E}$ \\
\hline Ecc13/96 & Korea & Pumpkin & 1996 & II & $\mathrm{E}$ \\
\hline Ecc14/96 & Korea & Potato & 1996 & II & $\mathrm{G}$ \\
\hline Ecc1/97 & Korea & Pepper & 1997 & II & $\mathrm{G}$ \\
\hline Ecc2/97 & Korea & Calla & 1997 & II & $\mathrm{G}$ \\
\hline Ecc3/97 & Korea & Potato & 1997 & II & $G$ \\
\hline Eccl/98 & Korea & Cactus & 1998 & II & $\mathrm{E}$ \\
\hline
\end{tabular}

a) Group and cluster analyses on the basis of fatty acid composition. See Fig. 1

b) MAFF, Ministry of Agriculture, Forestry and Fisheries Genebank, Japan 
strains were stored in freezing medium (skim milk $100 \mathrm{~g}$, sodium glutamate $10 \mathrm{~g}$, distilled water 1 liter) at $-70^{\circ} \mathrm{C}$. When required, all strains were grown on MGY agar (mannitol $10.0 \mathrm{~g}, \mathrm{~L}$-glutamic acid $2.0 \mathrm{~g}, \mathrm{KH}_{2} \mathrm{PO}_{4} 0.5 \mathrm{~g}, \mathrm{NaCl} 0.2 \mathrm{~g}, \mathrm{MgSO}_{4} \cdot 7 \mathrm{H}_{2} \mathrm{O} 0.2 \mathrm{~g}$, yeast extract $0.25 \mathrm{~g}$, agar $15.0 \mathrm{~g}$, distilled water 1 liter, $\mathrm{pH} 7.0$ ) (Keane et al., 1970 ) at $28^{\circ} \mathrm{C}$ for 2 days.

\section{Preparation of the samples}

Extraction of whole cellular fatty acids was conducted by the method of Gudmestad et al. (1988) with slight modifications. Bacterial strains were cultured for 2 days on King's B agar. Portions (approximately $5 \mathrm{mg}$, fresh weight) of cells were methylated with $0.5 \mathrm{ml} 5 \% \mathrm{HCl}-$ methanol at $100^{\circ} \mathrm{C}$ for $3 \mathrm{hr}$ in a sealed glass tube to obtain fatty acid methyl ester (FAME) derivatives. After methanolysis, one ml of water was added and the FAMEs were extracted with petroleum ether by shaking. The solvent phase was washed with equal volume of distilled water to remove $\mathrm{HCl}$ and dehydrated by mixing with $0.5 \mathrm{~g}$ anhydrous sodium sulfate. The organic phase was concentrated by blowing nitrogen gas. Samples were stored at $-20^{\circ} \mathrm{C}$.

\section{Analysis of cellular fatty acids}

Two microliters of the concentrate was injected into a GLC chromatograph (Shimadzu C-R-7A Plus) equipped with HR-SS-10 capillary column. The column and injection-port temperature were maintained at $180^{\circ} \mathrm{C}$ and $250^{\circ} \mathrm{C}$, respectively, and the flow rate of nitrogen gas was $50 \mathrm{ml} / \mathrm{min}$. Under these conditions, methyl esters were separated in about $15 \mathrm{~min}$. Fatty acids were identified by comparison of retention times with those of 21 purified reference standards. Euclidean distance among the strains based on fatty acid composition was assessed with average linkage cluster analysis procedure using the statistic package software SYSTAT.

\section{RESULTS AND DISCUSSION}

Fatty acid profiles can be affected by culture conditions, physiological age of cells, and experimental factors in the laboratory (Casano et al., 1986). KB medium was selected for this study because the greater diversity of fatty acids detected in cells grown on $\mathrm{KB}$ than in cells grown on TSA medium (Wells and Moline, 1991).

Vaccenic acid (18:1 cis 11), palmitoleic acid (16:1 cis 9), palmitic acid (16:0), lauric acid (12:0), and one unidentified fatty acid (Un-3) were present in all the 87 strains. Capric acid (10:0), myristic acid (14:0), 3-hydroxylauric acid (12:0 3-OH), stearic acid (18:0), linoleic acid (18:3 cis 9,12) and four unidentified fatty acids (Un-1, Un-2, Un-4 and Un-5) were found in some but not all strains. De Boer and Sasser (1986) reported that the Ecc and Eca could be differentiated by some of the calculations based on the ratio of 12:0/14:0 and 16:0/12:0. Values for these ratios of $<3.71$ and $>4.87$, respectively, were used as benchmarks for Eca strains, while the contrasting values, $>3.71$ and $<4.87$ were used as benchmarks for Ecc strains. In our study, all strains except one strain (S8488) were below 3.1 for the ratio of 16:0 divided by 12:0. However, 24 out of 87 strains were not accordance with the ratio of 12:0 divided by 14:0 for Ecc. These results indicated that the intermediate strains could be distinguished from both typical Ecc and Eca in fatty acid composition. 
A partial relationship between the fatty acid compositions and geographical origins was found. Mean percentage of unidentified fatty acid (Un-5) for Korean strains were significantly higher than that for Thai and Japanese strains (Table 2). In cluster analysis

Table 2. Percentage of fatty acids in 87 strains of $E$. carotovora subsp. carotovora isolated from Thailand, Korea and Japan

\begin{tabular}{|c|c|c|c|c|c|c|}
\hline \multirow{3}{*}{ Fatty acid } & \multicolumn{2}{|c|}{ Thai $(\mathrm{n}=22)^{\mathrm{b})}$} & \multicolumn{2}{|c|}{ Korean $(n=23)$} & \multicolumn{2}{|c|}{ Japanese $(n=42)$} \\
\hline & \multicolumn{2}{|c|}{ Relative \% present } & \multicolumn{2}{|c|}{ Relative \% present } & \multicolumn{2}{|c|}{ Relative $\%$ present } \\
\hline & Range & Mean $\pm S D^{c}$ & Range & Mean $\pm S D$ & Range & Mean $\pm S D$ \\
\hline $10: 0$ & $0.0-11.6$ & $3.9 \pm 3.2$ & $0.0-12.9$ & $4.2 \pm 3.5$ & $0.0-18.0$ & $4.5 \pm 4.6$ \\
\hline $12: 0$ & $6.3-15.7$ & $10.2 \pm 2.0$ & $7.0-18.1$ & $11.4 \pm 2.7$ & $2.1-20.2$ & $10.5 \pm 2.8$ \\
\hline $14: 0$ & $0.7-5.7$ & $2.6 \pm 1.2$ & $0.0-9.2$ & $1.7 \pm 1.9$ & $0.0-10.6$ & $2.2 \pm 2.3$ \\
\hline Un-1 $1^{\text {a) }}$ & $0.0-9.8$ & $1.1 \pm 2.1$ & $0.0-1.5$ & $0.1 \pm 0.4$ & $0.0-2.5$ & $0.3 \pm 0.6$ \\
\hline $16: 0$ & $10.7-22.4$ & $17.4 \pm 2.9$ & $9.2-19.9$ & $14.3 \pm 3.1$ & $10.2-31.8$ & $19.5 \pm 4.6$ \\
\hline $16: 1$ cis 9 & $15.2-26.2$ & $19.4 \pm 2.8$ & $14.2-25.0$ & $18.3 \pm 2.8$ & $4.3-33.7$ & $22.7 \pm 5.8$ \\
\hline Un-2 & $0.0-2.4$ & $0.5 \pm 0.6$ & $0.0-3.6$ & $0.2 \pm 0.7$ & $0.0-2.4$ & $0.3 \pm 0.5$ \\
\hline $12: 03-\mathrm{OH}$ & $0.0-1.7$ & $0.5 \pm 0.5$ & $0.0-6.3$ & $0.3 \pm 1.3$ & $0.0-2.1$ & $0.3 \pm 0.5$ \\
\hline $18: 0$ & $0.0-0.9$ & $0.3 \pm 0.2$ & $0.0-4.3$ & $0.3 \pm 0.9$ & $0.0-2.2$ & $0.5 \pm 0.7$ \\
\hline Un-3 & $5.1-15.3$ & $9.0 \pm 2.4$ & $4.6-11.2$ & $7.0 \pm 1.9$ & $1.6-22.7$ & $10.3 \pm 3.7$ \\
\hline Un-4 & $0.0-0.5$ & $0.2 \pm 0.2$ & $0.0-1.6$ & $0.2 \pm 0.4$ & $0.0-1.7$ & $0.2 \pm 0.3$ \\
\hline $18: 3$ cis 9,12 & $0.0-2.5$ & $0.3 \pm 0.5$ & $0.0-0.3$ & $0.0 \pm 0.1$ & $0.0-9.5$ & $0.2 \pm 1.9$ \\
\hline $18: 1$ cis 11 & $17.5-46.6$ & $34.2 \pm 7.3$ & $28.5-53.4$ & $39.9 \pm 6.4$ & $6.9-51.7$ & $28.2 \pm 11.1$ \\
\hline Un-5 & $0.0-1.5$ & $0.3 \pm 0.4$ & $0.0-8.9$ & $2.2 \pm 2.4$ & $0.0-3.1$ & $0.3 \pm 0.7$ \\
\hline
\end{tabular}

a) Un-, unidentified

b) $n$, number of strains

c) $\mathrm{SD}$, standard deviation

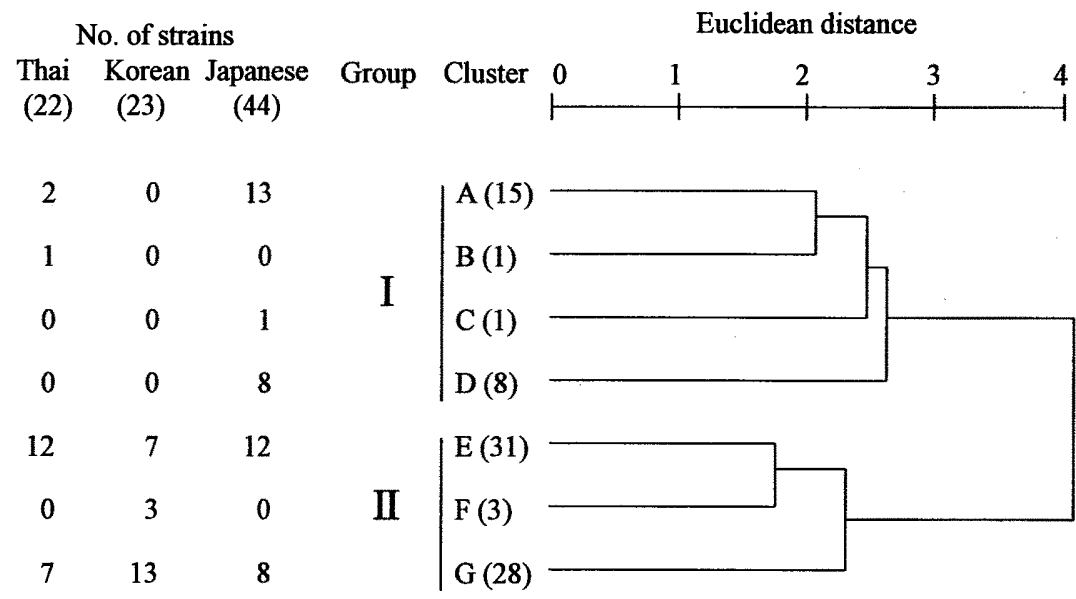

Fig. 1. Relationships among 87 strains of $E$. carotovora subsp. carotovora on the basis of fatty acid composition. Groups and clusters are indicated on the left. Numbers of strains are in parentheses. 
based on fatty acid composition, the Ecc strains were composed of two groups (I and II) and seven clusters (A-G). Most of strains used in this study belonged to cluster $A, E$ and G. All Korean and most of Thai strains belonged to the group II, while Japanese isolates belonged to the both groups (Fig. 1).

Further studies with larger numbers of strains and analysis under different cultural conditions will be required to understand relationships among geographic origins of the pathogen.

\section{REFERENCES}

Casano, F. J., J. M. Wells and T. Van der Zwet 1986 Fatty acid profiles of Erwinia amylovora as influenced by growth medium, physiological age, and experimental conditions. J. Phytopathol., 121: $267-274$

Darrasse, A., S. Priou, A. Kotoujansky and Y. Bertheau 1994 PCR and restriction fragment length polymorphism of a pel gene as a tool to identify Erwinia carotovora in relation to potato diseases. Appl. Environ. Microbiol., 60: 1437-1443

De Boer, S. H. and M. Sasser 1986 Differentiation of Erwinia carotovora ssp. carotovora and $E$. carotovora ssp. atroseptica on the basis of cellular fatty acid compositon. Can. J. Microbiol., 32: $796-800$

De Boer, S. H., L. Verdonck, H. Vruggink, R. Harju, H. O. Bang and J. De Ley 1987 Serological and biochemical variation among potato strains of Erwinia carotovora subsp. atroseptica and their taxonomic relationship to other E. carotovora strains. J. Appl. Bacteriol., 63: 487-495

Gudmestad, N. C., P. J. Henningson and W. M. Bugbee 1988 Cellular fatty acid composition of strains of Corynebacterium michiganense subsp. sepedonicum from potato and sugar beet. Can.J. Microbiol., 34: 716-722

Keane, P. J., A. Kerr and P. B. New 1970 Crown gall of stone fruit. II. Identification and nomenclature of Agrobacterium isolates. Aust. J. Boil. Sci, 23: 585-595

Lelliot, R. A. and R. S. Dickey 1984 Genus VII. Emvinia Winslow, Broadhurst, Buchanan, Krumwiede, Rogers and Smith 1920, 209 ${ }^{\mathrm{AL}}$, p. 469-476. In: Krieg NR and Holt JG (eds) Bergey's manual of systematic bacteriology, vol. 1. Williams and Wilkins Co., Baltimore

Moss, C. W. 1981 Gas-liquid chromatography as an analytical tool in microbiology. J. Chromatogr., 201: $337-347$

Smith, C. and J. A. Bartz 1990 Variation in the pathogenicity and aggressiveness of strains of Ecc isolated from different hosts. Plant Dis., 74: 505-509

Wells, J. M. and H. E. Moline 1991 Differentiation of the soft-rotting Erwinias (the carotovora group) by fatty acid compositon. J. Phyotopathol., 131: 22-32 